Journal of Teachers of English

Volume 5 No. 2, 2020

e-ISSN: 2548-6810

\title{
THE CORRELATION BETWEEN STUDENTS' INTERPERSONAL AND INTRAPERSONAL INTELLIGENCES AND THEIR ENGLISH ACHIEVEMENT AT SMAN 2 KENDARI
}

Iin Ibrahim ${ }^{1}$, Firdaus Sale ${ }^{2}$, Wa ode Fatmawati ${ }^{3}$

1,2,3 Halu Oleo University, Indonesia.

\begin{tabular}{l}
\multicolumn{1}{c}{ ARTICLE INFO } \\
\hline Keywords: \\
Students' Interpersonal \\
Intelligences, Students \\
Intrapersonal \\
Intelligences, English \\
Achievement. \\
How to cite: \\
\\
DOI:
\end{tabular}

\begin{abstract}
The purpose of this study was to investigate the correlation between students' interpersonal and intrapersonal intelligences and their English achievement. The design of this study was correlation design, and the sample of this study was 90 students which is consists of 140 populations. The sampling was taken by simple random sampling. Moreover, the instruments of this study were interpersonal and intrapersonal intelligences. Based on the result of data computation, it showed that coefficient correlation of students' interpersonal with $(r=-$ .214).), indicates a low correlation, while students intrapersonal has the high correlation with $(r=0.071)$. The result also shown that the significant value of each students' interpersonal and intrapersonal intelligences had a significant correlation with their English achievement because its probability value (sig.2 tailed) 0.040 and 0.000 were higher than 0.05 . so H1 is definitely accepted and H0 is totally rejected.
\end{abstract}

\section{Introduction}

Based on interview with the teacher and student when the researcher went to SMAN 2 Kendari to interview about the process learning and teaching of English lesson at class, it seems that, the learning and teaching English lesson process didn't run well because the students' attention are low toward the topic. Students feel weighed down by the lessons. They felt English is a difficult lesson. Only a few students who already have basics English interested to listen the material that presented by the teacher. Only some students who sit in front of class are active toward the learning process. Another talked to other friends.

One of the problem of student at Eleventh Grade of SMAN 2 Kendari in academic years 2018/2019 is the lack of learner's desire to learning of English, because student's knowledge about English lesson are still less and limited, so that, the teacher tried to gave them a lower English t,opic, because only some of students 
that could be understand of English material in process of learning and teaching in English. Teacher's difficulty in the process learning and teaching English lesson is how to vary the teaching strategy for students can be more focused and motivated in learning of English. Statement one of English teacher at SMAN 2 Kendari when process teaching and learning in English, only student intrapersonal or who have high self efficacy that always focused, and can to be understand quickly about the English lesson, while students' interpersonal are not too active and a bit understanding about English lesson.

Based on interview with the students about the learning and teaching of English lesson process, it seems that the students have different strategy in learning English. One of statement of students who have high self esteem or student intrapersonal said that she prefer to learn new English words by reading an English book, make lists of new vocabularies, searching for the meaning of an unknown words and prefer to learn alone rather than in groups. While statement one of students who have good communication skill or students' interpersonal said that she prefer to learn English through learning in groups like asking to her friends about the meaning of unknown words and discuss to other friends about the difficult English lesson.

In fact, students' interpersonal and intrapersonal at SMAN 2 Kendari in academic years 2018/2019 learn of English by using differen strategies in order to increase their English achievement. So that, teacher provides materials which enable the student to develop their English skill and increase their achievement. The aim of the class are that the students will be able to use a variety of basic language functions such as greeting, asking information, and expressing opinions by developing vocabularies that they already know, the students will be able to apply simple pronunciation related to sound, rhythm, emphasis, and intonation to improve their English, So students can be confidence and fluently in English. Students of Eleventh Grade of SMAN 2 Kendari in academic years 2018/2019 have two kinds of students. One is interpersonal students and the other is intrapersonal students. Students who were interpersonal intelligence prefer to use interpersonal strategies and those who were intrapersonal intelligence prefer to use intrapersonal strategies in learning English.

Before discussing theories on intelligence, it is important to first define the concept. Definition range from the concise "the intellectual ability for solve problem" to the details: Intelligence is a very general mental capability that, among other things, involves the ability to reason, plan, solve problems, think abstractly, comprehend complex idea, learning quickly and learn from experience. It is not merely book learning, a narrow academic skill, or test taking smarts. Rather it reflects a broader and deeper capability for comprehending our surrounding--"catching on", "making sense" of things, or "figuring out" what to do. (Gottfredson, 1997). Wechsler (1981) talked about intelligence by saying that it is global skill to act purposefully, to think rationally, and to interact effectively with his environment which means that intelligence is not a one entity but a combination of several entities" (p.2). Another, Binet and Simon (1916) stated that intelligence could be identified as judgment by which an individual must be adjusted with the 
circumstances of a particular situation. So, whether the person is stupid or not only good judgment would make a significant difference.

There are many experts are giving their opinion about interpersonal intelligence. According to Gardner (1983), an individual who is high in interpersonal intelligence understands the intentions, motivations, needs, and desire of others, and is capable of working effectively with them. Moreover, Weber (2005) states that "interpersonal, is a skill to observe and respond appropriately to the moods, character, motivations, and desires of other people" (p.4). Another, Pishghadam (2009) argues that "interpersonal intelligence is the ability to know others' desire, feelings, and intentions". Close similarly, "interpersonal intelligent as the ability to notice and make distinctions among other individuals with respect to moods, temperaments, motivations, intensions, and to use this information in pragmatic ways, such as to persuade, influence, manipulate, mediate, or counsel individuals or groups of individuals toward some purpose.

In addition, Tan (2008) interpersonal (social) intelligence is the capacity of understanding, distinguishing and welcoming the emotions, aspirations and needs of surrounding people. It means that interpersonal intelligence as an ability to understand the intentions, motivations and desires of other people or they have a good communication styles and understanding of feeling's other people.

Intrapersonal intelligence is the capacity to understand oneself and one's thoughts and feelings, and to use such knowledge in planning and directionning one's life.

In defining intrapersonal intelligence there are many experts are giving opinion about intrapersonal intelligences. Gardner (1999) argues that "intrapersonal intelligence as the ability to understand and to have an effective working model of oneself Intrapersonal intelligence is an ability to recognize and understand one's own moods, desire, motivations, and intentions. Armstrong (2003) states that "intrapersonal intelligence is the ability to access one's own emotional life through awareness of inner moods, intentions, motivations, potentials, temperaments, and desires, and the capacity to symbolize these inner experiences, and to apply these understandings to help one live one's life".

Like previous research, in line Pishghadam (2009) who examined the role of intelligence in language learning. His study compared the interpersonal and intrapersonal intelligence and student's score language skills: reading, speaking, listening and writing as well as students' GPA. The findings indicated that a higher level of intelligence was a significant predictor of a higher GPA. The higher level of intelligence was also linked to higher score in language skills which significantly depend on intelligence abilities: speaking (which was linked interpersonal and intrapersonal intelligence). Listening (which was linked to the interpersonal skills and stress management), reading (which depends on stress management, adaptability and general mood)., as well as writing (connected to adaptability and stress management). In addition, Ahmad (2014) examine the relationship between emotional intelligence and Iranian EFL learners speaking proficiency found that intrapersonal show a great relation with speaking proficiency but interpersonal tends to have a weak negative relation with speaking proficiency other components of EI show negligible relations. 
Related to the background above, the researcher determined the problem statements as follow:

1. Is there any significant correlation between students' interpersonal intelligences and their English achievement?

2. Is there any significant correlation between students' intrapersonal intelligences and their English achievement?

\section{Methodology}

The design of the study was correlation Design. The population in this study consists of five classes in X1 IPA. The total populations of this study were 140 students. The instrument of this study was the questionnaire of interpersonal and intrapersonal intelligences and also completed with the students' English achievement of school report card semester 1 from the English teacher of SMA Negeri 2 Kendari.

First, researcher used Cronbach's Alpha coefficient. Crobach's Alpha coefficient is a measurement of internal consistency reliability of an instrument used in a research (Cronbach, 1951). In this study it used to testing the reliability of interpersonal and intrapersonal questionnaire. Second, descriptive statistics, is statistical procedures that organize and summarize research data. In this study it used to determine the students' interpersonal and intrapersonal intelligences. It includes frequency counts, percentage of the questionnaire. It is allowing researcher to describe and summarize.

\section{Result and Data Analysis}

Table of The Correlation Coefficient of Students' Interpersonal Intelligences and Their English Achievement

\begin{tabular}{|lll|r|r|}
\hline \multicolumn{2}{|c|}{ Correlations } \\
\hline & & $\begin{array}{c}\text { Students' } \\
\text { interpersonal } \\
\text { intelligences }\end{array}$ & $\begin{array}{c}\text { Their English } \\
\text { achievement }\end{array}$ \\
\hline $\begin{array}{l}\text { Spear } \\
\text { man's }\end{array}$ & Students' & Correlation Coefficient & 1.000 & $-.214^{*}$ \\
rho & intelligence & Sig. (2-tailed) &. & .040 \\
& Their English & Correlation Coefficient & 90 & 90 \\
& achievement & Sig. (2-tailed) & $-.214^{*}$ & 1.000 \\
& & $\mathrm{~N}$ & .040 & .90 \\
\hline
\end{tabular}

From the correlation table as can be seen from table 4.8 above, it shows that the students' interpersonal intelligence had a significant correlation with their English achievement because its probability value (sig.2-tailed) $\leq 0.05$ showed by $(\alpha=0.040)$. The criteria of students' interpersonal intelligence is a low correlation (see on table 4.11) with $(r=-.214)$. Then last, the result shows that the correlation coefficient was negative $(r=-.214)$. It means that there is a significant correlation 
between students' interpersonal intelligence and their English achievement with a negative influence, which it shows that the higher students' interpersonal intelligence but the lower their English achievement.

Table of The Correlation Coefficient of Students Intrapersonal Intelligences and Their English Achievement

\begin{tabular}{|c|c|c|c|c|}
\hline \multicolumn{5}{|c|}{ Correlations } \\
\hline & & & $\begin{array}{c}\text { students' } \\
\text { intrapersonal } \\
\text { intelligences }\end{array}$ & $\begin{array}{l}\text { Their English } \\
\text { Achievement }\end{array}$ \\
\hline \multirow{6}{*}{$\begin{array}{l}\text { Spearma } \\
\text { n's rho }\end{array}$} & \multirow{3}{*}{$\begin{array}{l}\text { Students } \\
\text { Intrapersonal } \\
\text { intelligence }\end{array}$} & Correlation Coefficient & 1.000 & .071 \\
\hline & & Sig. (2-tailed) & & .000 \\
\hline & & $\mathrm{N}$ & 90 & 90 \\
\hline & \multirow{3}{*}{$\begin{array}{l}\text { Their English } \\
\text { achievement }\end{array}$} & Correlation Coefficient & .071 & \multirow[t]{3}{*}{1.000} \\
\hline & & Sig. (2-tailed) & .000 & \\
\hline & & $\mathrm{N}$ & 90 & \\
\hline
\end{tabular}

From the correlation table as can be seen from table 4.9 above, it shows that the students intrapersonal intelligence had a significant correlation with their English achievement because its probability value (sig.2-tailed) $\leq 0.05$ showed by $(\alpha=0.000)$. The criteria of students intrapersonal intelligence is a high correlation (see on table 4.11) with $(r=.071)$. Then last, the result shows that the correlation coefficient was positive $(r=.071)$. It means that there is a significant correlation between students intrapersonal intelligence and their English achievement with a positive influence, which it shows that the higher students' intrapersonal intelligence, the higher their English achievement.

Based on the criteria of correlation degree by Arikunto (2002) the correlation can be categorized as low, moderate and high correlation. (see Table 4.11)

Table 4.7 The Correlation Coefficient Interpretation

\begin{tabular}{|c|c|}
\hline Interval Coefficient & Correlation Degree \\
\hline $0.00-0.199$ & Very Low \\
\hline $0.20-0.399$ & Low \\
\hline $0.40-0.599$ & Moderate \\
\hline $0.60-0.799$ & High \\
\hline $0.80-1.000$ & Very High \\
\hline
\end{tabular}

Based on explanation above, the researcher takes some conclusions. First, the result of the analysis has shown that students' interpersonal intelligences has a low correlation with their English achievement and students intrapersonal intelligence has high correlation with their English achievement. Second, The result also shows that all of aspects of students' interpersonal and intrapersonal intelligences had a 
significant correlation with their English achievement because its probability value (sig.2-tailed) 0.040 and $0.000<0.05$ it means that there is a significant correlation between students' interpersonal and intrapersonal intelligences and their English achievement. Hence, $\mathrm{H}_{1}$ of this study was accepted and $\mathrm{H}_{0}$ was rejected.

\section{Discussion and Conclusion}

Based on Spearman Rho correlation, the result of this study showed that there is a significant correlation between students' interpersonal and intrapersonal intelligences and their English achievement. English achievement is associated with students' interpersonal and intrapersonal intelligences, it can be seen from the probability value (sig.2-tailed) 0,040 and $0,000<0.05$. It means that there is a significant correlation between students' interpersonal and intrapersonal intelligences and their English achievement. Hence, $\mathrm{H}_{1}$ is accepted. The criteria of the correlation between students' interpersonal intelligences and their English achievement is a low correlation with $(r=-.214)$.) means that the contribution of the students' interpersonal intelligences to the English achievement is a low while the criteria of the correlation between students' intrapersonal intelligences and their English achievement is high correlation with $(r=0.071)$ means that the contribution of the students intrapersonal to the English achievement is high. Then last, the result shows that the coefficient correlation of students' interpersonal was negative $(r=-$ .214).), and the coefficient correlation of intrapersonal was positive $(r=.071)$.

In line Pishghadam (2009) who examined the role of intelligence in language learning. His study compared the interpersonal and intrapersonal intelligence and student's score language skills: reading, speaking, listening and writing as well as students' GPA. The findings indicated that a higher level of intelligence was a significant predictor of a higher GPA. The higher level of intelligence was also linked to higher score in language skills which significantly depend on intelligence abilities: speaking (which was linked interpersonal and intrapersonal intelligence). Listening (which was linked to the interpersonal skills and stress management), reading (which depends on stress management, adaptability and general mood)., as well as writing (connected to adaptability and stress management).

In addition, Ahmad (2014) examine the relationship between emotional intelligences and Iranian EFL learners speaking proficiency found that intrapersonal show a great relation with speaking proficiency but interpersonal tends to have a weak negative relation with speaking proficiency other components of EI show negligible relations. Moreover, Genc, Kulusakli, and Aydin (2016) examine the relationship between emotional intelligence and productive language skill (writing and speaking). The findings showed that there is positive correlation on interpersonal and intrapersonal skills. They claimed that the more emotionally intelligence person may get rid of those problems easily and enhance language performance and a relaxing and healthy classroom atmosphere which enables students to get relaxed is needed to promote speaking skills of the students. For all findings, it can be said that intelligences specifically on students' interpersonal and intrapersonal intelligences had a significant correlation with students' English achievement. Students with intrapersonal skill who better know about their strength 
and weakness would trigger their selves to be good in speaking when they face speaking problems because they may experience high self-confidence and are better at taking risky action (Genc, Kulusakli and Aydin, 2016). And also students with interpersonal who is helpful, good at cooperation and acting responsibility in social group. Students who have strong interpersonal intelligence own good understanding and interaction with other people and this fact affects their ability in speaking skills in second language (Ahmadi, 2014). It also has to do with the ability to socialize with others by taking social rules into consideration. Students having a high sense of social responsibility are not self oriented and they have a feeling of trust on others. Students with these features, they are all helpful and facilitating for the students to interact with others and communicate easily.

This study had been conducted to know the correlation between students' interpersonal and intrapersonal intelligences and their English achievement. The participant of this study was the second grade XI IPA that registered in academic year 2018/2019.

Then, students' English achievement, the data was gathered by taking the result of their achievement from the result of report card semester 1 . The researcher found the minimum score is 80 , maximum score is 95 , mean of raw score is 89.6 and the standard deviation is 3.11935 .

To sum up, there is any correlation between students' interpersonal and intrapersonal intelligences and their English achievement. So, it can be concluded that $\mathrm{H}_{1}$ is accepted and $\mathrm{H}_{0}$ was rejected. There is any significant correlation between students' interpersonal and intrapersonal intelligence and their English achievement at Eleventh Grade of SMA Negeri 2 Kendari

\section{References}

Ahmad, J. (2014). A quantitative analysis of the relationship between emotional intelligence and Irania EFL learners' speaking proficiency. Projournal of Humanities and Social Science, 2 (2), 71-83

Arikunto, Suharsimi. (2002). Prosedur Penelitian Suatu Pendekatan Praktek. Jakarta: Rineka Cipta

Armstrong,T. (2009) Multiple Intelligences in the classroom.3 $3^{\text {rd }}$ Edn., Alexandria, VA: The Association for Supervision and Curriculum Development.

Armstrong, T. (2003). Multiple Intelligences In the Classroom. United States of America: ASCD Publications.

Armstrong, T. (1999). 7 Kinds of Smart: Identifying and Developing Your Multiple Intelligences. New York, NY: Penguin Putnam.

Berman, M. (1998). A Multiple Intelligences Road to an ELT Classroom. Carmar: Crown House Publishing.

Binet, A., \& Simon, T. (1916). The Development of Intelligences In Children. Baltimore: Williams Wilkins.

Bruner, E. (2007). Cranial Shape and zise variation in human evolation: structure and functional perspective. Child's Nervous System, 23, 1357-1365. 
Budiawan, (2008). Pengaruh Sikap Bahasa dan Motivasi Belajar bahasa Terhadap Prestasi Pada Mata Pelajaran Bahasa Indonesia dan Bahasa Inggris Siswa Sebandar Lampung . Depok. Universitas Indonesia.

Christison, M. A. (1998). Applying Multiple Intelligences Theory In Pre-Service and In Service TELF Education, Programs. English Language Teaching Forum, 36(2), 2-13 Multiple Intelligences. ESL Magazine, 2(5), 10-13

Djamarah, Syaiful Bahri. (2002). Prestasi Belajar dan Kompetensi Guru. Surabaya: Usaha Nasional.

Gardner, H. (1999). Multiple intelligences: The Theory and Practice, New York Basic Books.

Gardner, H (1983). Frames of Mind: The Theory of Multiple Intelligences. United States of Americas: Basic Books.

Gottfredson, L.S (1997). Mainstream Science on Intelligences An Editorial with 52 signatories, history, and bibliography. Intelligence, 24, 13-23

Guilford, J. P. (1967). The nature of human Intelligences. New York: McGraw-Hill

Hallonen, Jane S and Santrock, John W. 1999. Psychology: Applied and Application 3rd. USA : Mc Graw-Hill Colage.

Hodges, D. A. (1996) . Newron Musical Research: A Review Of The Literature . In D.A. Hodges (Ed), Handbook of Music Psychology (pp.197-284). Lawrence, KS: National Association for Music Theraphy.

Hornby, A.S. (1995). Oxford advancel Learner Dictionary. Oxford: Oxford University Press.

Johnson, B., \& Christensen, L., (2000). Educational Research: Quantitative and qualitative approaches, Boston: Allyn \& Bacon.

Kaplan, M 2007, What is intelligences? Viewed 25 , June, 09, http:// www.anapsid.org/herpintelligence,html

Mckenzie, W., 2005. Multiple Intelligences and Istructional Technology International Society for Technology in Education.

McKenzie, W.,1999, Multiple Intelligences survey. Available from http://surfaquarium.com/MI/.

Piaget, Jean (1952) The Origins of Intelligence In The Child. London: Routledge and Kegan Paul.

Pisghadam, R. (2009). A quantitative analysis of the relationship between emotional intelligence and foreign language. Electronic Journal of Foreign Language Teaching, 6 (1), 31-41.

Ratnawati, Mila. (1996). Hubungan Antara Persepsi Anak Terhadap Suasana Keluarga, Citra Diri, dan Motif Berprestasi dengan Prestasi Belajar Pada Siswa Kelas V SD Ta'Miriyah Surabaya. Jurnal Anima Vol XI No, 42.

Riduwan. (2004). Metode dan Teknik Menyusun Tesis. Bandung : Alfabeta

Spearman, Charles. (2003) Genera Intelligence Objectively Determined and Measured. American Journal of Psychology. 15, 201-293. 
Spearman, Charles. (1904). General Intelligence, Objectively Determined and Measured. American Journal Psychology.

Stanford, P. (2003). Multiple intelligence for every classroom. Intervention in school and Clinic, 39(2), 80-85

Sternberg, R.J. (1985). Beyond IQ: A Triarchic Theory of Human Intelligence. Cambridge: Cambridge University Press.

Sugiyono. (2010). Metode Penelitian Kuantitatif Kualitatif dan RED. Bandung: Alfabet.

Sugiyono. (2008). Metode Penelitian Kuantitatif dan Kulitatif E RND.Bandung.

Alfabeta

Sugiyono. (2003). Metode Penelitian Bisnis. Alfabeta:Bandung.

Sutomo. (2014). A Study of Factors InfluenceStudents' English Achievement at Junior High School 2 Kendari. Unpublished Thesis.

Tan, D. (2008). Attitudes and attraction: A developmental study of the dissimilari ty repulation hypotheses. Personality and social psychology bulletin.

Teele, S. (1995). The mulitiple intelligences school: A place for all students to succeed. Redlands, CA: Citrograph.

Teriska, Siska. 2011. Language Anxiety in Speaking English. A Descriptive Study on Second Graders of Senior High School. Digital Library UPI.

Travers, John., P. (1970). Fundamental of Educational Psychology. Scrantom, Pensylvania: International Textbook Company.

Vygotsky, L.S. (1929) The Problem of The Cultural Development Of The Child. Journal of Genetic Psychology. 36, 415-434.

Weber, E. (2005). MI strategies in the classroom and beyond: using roundtable learning. USA: Pearson Education, Inc.

Wechsler, D. (1981). Wechsler Adult Intelligence Scale-Revised. Manual. New York: Psychological Corporation. 